\title{
Manipulation of Nonsense to Bring Sense: The Pinter Technique
}

\author{
Anuradha S., R.Udhya Kumar
}

\begin{abstract}
Harold Pinter, the Nobel laureate, is a literary giant of modern drama in English. His plays are categorized as belonging to the absurd theatre along with the likes of Beckett. The absurd theatre makes use of language in a peculiar way to communicate the real predicament of human existence. Harold Pinter, as a chief exponent of the Absurd Theatre made a significant stamp on the theatrical language. His style is so unique that it led to the coinage of the word 'Pinteresque'. The speeches in his plays are an interplay of both sense and nonsense. This article aims to analyze the language employed by Harold Pinter and in the process examine how absurd it actually is.
\end{abstract}

Keywords : Absurd, expression, language, meaning, purpose, silence,

\section{INTRODUCTION}

After the World Wars, people were afflicted with depression and anger caused by trauma. Writers and dramatists expressed their anguish in their own ways. "Existentialism speaks powerfully to the sense of the 20th century as a chaotic and even catastrophic era, in which certainties have been lost and man is faced with the abyss of nothingness, or of his own capabilities for evil." (Wynne 214) Absurd theatre grew out of such negativity as a reaction against it. The Theatre of the Absurd rocked the literary world with its unconventional, extraordinary use of language. Absurd Theatre projects life as meaningless and purposeless which is how they could have perceived it given their situation. The language employed by the dramatists of the Absurd theatre comes closest to colloquial everyday language of commoners. However, the plays of Absurdists are at the same time far removed from realism. They tease the audience to understand them. They employ a lot of nonsense. The plays selected here for analysis are The Birthday Party and One for the Road.

\section{METHODOLOGY}

\section{A. SENSE THROUGH NONSENSE}

Pinteresque language has received mixed reactions. Pinter's language is one filled with "mumbling, repetitiveness, poor grammar, incomplete sentences, non

Revised Manuscript Received on December 30, 2019.

* Correspondence Author

Anuradha S.*, Assistant Professor, Vel Tech Rangarajan Dr. Sangunthala Institute of Science andTechnology Chennai.

R.Udhya Kumar, Assistant Professor, Vel Tech Rangarajan Dr. Sangunthala Institute of Science and Technology, Chennai

(C) The Authors. Published by Blue Eyes Intelligence Engineering and Sciences Publication (BEIESP). This is an open access article under the CC BY-NC-ND license (http://creativecommons.org/licenses/by-nc-nd/4.0/) sequiturs, sudden shifts of subject matter, refusal or inability to leave a subject another character has left, and the like" (Dukore 4). It is almost always that the words uttered by Pinter's characters are just verbal forms of images in their minds. Their words are not what they speak but what thoughts they are clinging to and unable to let go. For instance, in The Birthday Party, Meg asks Petey if the cornflakes she fixed for him are nice repeatedly. The plays are filled with dialogues which are mere repetitions - The opening dialogue itself is repetitive. Meg asks Petey, "Is that you Petey?"(1) more than three times. Then she asks if the cornflakes are nice yet again several times.

\section{RESULT AND DISCUSSION}

The reluctance to let go of a topic or idea or feeling is evident through all his characters. When they utter a phrase or a sentence or a word, it's like they are stuck to it mentally. As they are struck mentally by a thought, they are unable to move on. They hold on to the same thought or feeling however uncomfortable and disturbing they might be. The reason being plain fear of what is to follow. There is not much to look forward to. The bleakness of life is a stark reality which slaps on the face of hope and expectation. Since the characters share this fear of reality, they are unwilling to face it. Instead they choose to talk about irrelevant things. There is an unnecessary stress laid on unimportant things while speaking. The focus is not to bring attention towards something but to remove the attention from what is ailing or disturbing. This can be seen play The birthday party, where after Stanley is carried away to an asylum, Meg is boasting of how lovely the party was.

"Meg. Wasn't it a lovely party last night?

Petey. I wasn't there.

Meg. Weren't you?" (87)

Petey allows Meg to revel in her delusion instead of discussing the reality of Stanley's exit.

It has to be understood that Pinter has made the dialogues more natural because "real-life conversations don't proceed smoothly and logically from point to point" (Kennedy 168).

Another accusation levelled against Pinter is that he hides a lot of information. Pinter never reveals the true identity of any of his characters. There is an element of mystery surrounding all his characters. Audience get to see only the tip of the iceberg. Pinter is rightly defended by Mishra, according to whom "words are, in fact, more evocative than descriptive in nature" (Misra 64). Absurd Theatre is commonly associated with the inability of language to communicate. 
Pinter is not concerned about the ineffectiveness of language. He is concerned about how people are evasive while communicating. People are scared of revealing their identities since they believe it would harm them. Pinter does not argue that language is useless. "He rather tries to explore the dramatic possibilities of low-life idiom and conversational speech, in projecting the complex psychological states of modern life" (Misra 152). In the plays of Pinter there is a lot of meaningless conversations. For example, in The Birthday Party, the conversations between the husband and wife Petey and Meg are by large meaningless banter. Meg talks to hide the sordid reality of life and to take refuge in a world of her hallucinations. Her world is what she had created in her little head. Her repetitive meaningless chatter gives rise to humour. But underneath the humour lies a pathos of her actual predicament which she seeks to hide from. When there isn't any sense in the existence there cannot be much sense in the language spoken as well.

Characters of Pinter's plays tend to hesitate often and this hesitation is shown in the plays with three dots. This hesitation is to avoid giving actual information.

"Meg. Is Stan down yet, Petey?

Petey. No... he's ...

Meg. Is he still in bed?

Petey. Yes, he's ... still asleep." (86)

Language is used more for manipulation than for representing actuality. Goldberg and McCann's sinister catechism is only one example of Pinter's frequent deployment of a language where under what is said, another thing is being said.

"GOLDBERG. You need a long convalescence

MCCANN. A change of air.

GOLDBERG. Somewhere over the rainbow

MCCANN. Where angels fear to tread...

GOLDBERG. We'll make a man of you.

MCCANN. And a woman.

GOLDBERG. You'll be oriented.

MCCANN. You'll be rich.

GOLDBERG. You'll be.”(83-84)

There's a wide difference between the meaning and what is actually meant. As Mark Taylor-Batty notes, "Political oppressors appear accommodating, upholding the rules and regulations of human rights, but they are ultimately tyrants" (Taylor-Batty 249).

In One for the Road, Nicolas claims to be a civilized man, "You're a civilized man. So am I."(1) The person who brutally tortures another person, rapes his wife, murders his son dares to call himself civilized. He is anything but civilized. It appears as if it does not make any sense. But Pinter has used this as the opening sentence precisely with the intention to point at the incongruity of so-called civilization.

Later, he claims, "God speaks through me.”(4) Here God is not the God, the merciful but the all-powerful man who runs the country. This same reference can be seen in his statement: "Your father fought for his country...He believed in God. He didn't think, like you shitbags."(12)

In the end he says, "I feel we've both benefitted from our discussions."'(15) There has never been a discussion or even a conversation. Throughout the play Nicolas has been threatening, bullying and torturing Victor and his family with his monologues. Nicolas never means what he says except when he is threatening his victims.

One for the Road - The title itself is incongruous. One for the road is a final drink before leaving on a journey. Nicolas is not going anywhere, definitely isn't leaving the building, certainly not hitting the road. Yet, he keeps repeating the phrase 'one for the road'. It's not just one final drink but a series of drinks he takes but claims that each one is for the road. It is neither the final drink nor is he leaving to anywhere. It is just a repetition which is symbolic of the nonsensical niceties exchanged in the so-called civilized world. The pleasantries and niceties are entirely meaningless. They in fact heighten the unpleasant and terrorize victims. Tautology is the means they adopt to establish their oppression. An example of this can be seen below:

"GOLDBERG. Do you recognize an external force?

STANLEY. What?

GOLDBERG. Do you recognize an external force?

MCCANN. That's the question.

GOLDBERG. Do you recognize an external force, responsible for you, suffering for you?

STANLEY. It's late.

GOLDBERG. Late! Late enough! When did you last pray?

MCCANN. He's sweating!

GOLDBERG. When did you last pray?

MCCANN. He's sweating!

GOLDBERG. Is the number 846 possible or necessary?

STANLEY. Neither.

GOLDBERG. Wrong! Is the number 846 possible or necessary?

STANLEY. Both.

GOLDBERG. Wrong! It's necessary but not possible.

STANLEY. Both.

GOLDBERG. Wrong! Why do you think the number 846 is necessarily possible?

STANLEY. Must be.

GOLDBERG. Wrong! It's only necessarily necessary! We admit possibility only after we grant necessity. It is possible because necessary but by no means necessary through possibility. The possibility can be assumed after the proof of necessity." (50)

Pinter's intention is to make the audience feel certain experiences for which to happen there has to be no gap between the subject matter and the form which carries it. 'To deal with the meaning embodied in his plays it is necessary to bear in mind Beckett's description of James Joyce's work: Here form is content, content is form. His writing is not about something, it is that something itself' (Dukore 7). Meaning translates in the performance and is in the feelings evoked in the audience.

"This is a straight show

What do you mean?

No dancing or singing

What do they do then?

They just talk" (The Birthday Party 23). 


\section{CONCLUSION}

Pinter has used language also effectively to communicate the actual predicament of human existence in the modern world of terror unleashed by governments against the people. He evokes the feeling of terror without having to explain or reason the feeling. His purpose is to speak out against tyranny. Pinter's plays are his voice against oppression. Harold Pinter has made the best use of nonsense to bring out sense. Pinter's plays are absurd only in the sense that they belong to the Absurd theatre, as they are not irrational or meaningless. Chaos cannot be portrayed in an orderly fashion; same way the lack of sense and meaning in life can be portrayed only through nonsensical dialogues and absurd situations.

\section{REFERENCES}

1. Pinter, Harold. The Birthday Party. Grove Press: New York, 1965.

2. ---. One for the Road. Samuel French: UK, 1984.

3. Dukore, Bernard Frank. Harold Pinter. London: Macmillan, 1982.

4. Esslin, Martin. The Theatre of the Absurd. New York: Vintage Books, 2001.

5. Kennedy, Andrew. Six Dramatists in Search of a Language: Studies in Dramatic Language. London; New York: Cambridge UP, 1975.

6. Marion Wynne -Davies, Guide to English Literature, Bloomsbury Publishing Limited, London, 1989.

7. Misra, Chittaranjan. Harold Pinter, the Dramatist. New Delhi: Creative, 1992

\section{AUTHORS PROFILE}

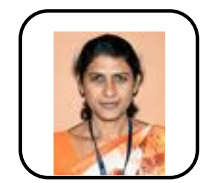

Ms. Anuradha S. M.A., M.Phil.,Research Scholar Assistant Professor,Vel Tech Rangarajan Dr. Sangunthala Institute of Science andTechnology

Chennai

Dr. R. Udhya Kumar MA., M.Phil., Phd.,Assistant ProfessorVel Tech Rangarajan Dr. Sangunthala Institute of Science and TechnologyChennai 